\title{
REDOX-SENSITIVE TRANSCRIPTION FACTORS EGR-1 AND SP1 IN THE PATHOGENESIS OF EXPERIMENTAL GASTRIC ULCER
}

\author{
S. M. BEREGOVYI ${ }^{1}$, T. M. CHERVINSKA ${ }^{1}$, A. S. DRANITSINA ${ }^{1}$, \\ S. SZABO', G. M. TOLSTANOVA ${ }^{1}$ \\ ${ }^{1}$ Educational and Scientific Centre Institute of Biology, \\ Taras Shevchenko National University of Kyiv, Ukraine; \\ ${ }^{2}$ University of California, Irvine, USA; \\ e-mail: gtolstanova@gmail.com
}

Changes in redox status of gastric mucosa cells are the main pathogenic factor of gastric erosion and gastric ulcer development. Pro-oxidants can affect cell transcription activity via changes in redox-sensitive transcription factors. Egr-1 and Sp-1 may regulate the transcription of genes that are associated with the pathogenesis of gastric ulcer (growth factors, cell cycle regulators, etc.). The aim of the present study was to reveal the possible involvement of zinc-finger transcription factors Egr-1 \& Sp-1 in the molecular mechanisms underlying gastric lesions caused by aspirin administration and stress. Gastric ulcer was induced in male rats (180-220 g) by immobilization stress combined with water-immersion (IMO-WI) or aspirin gavage $(10 \mathrm{mg} / 100 \mathrm{~g})$. The rats were euthanized $20 \mathrm{~min}, 1$ hour, or 3 hours following the ulcerogenic factor exposure. Protein expression was determined by Western blot analysis and RT-PCR; levels of SH-groups of proteins were determined by method of Ellman et al. Development of gastric ulcer lesions was associated with twofold $(P<0.05)$ decrease in concentration of protein SH-groups in the rat gastric mucosa. These changes were accompanied by significant $(P<0.05)$ increase in the expression of Egr-1 $m R N A$ and protein in both gastric ulcer models, and the changes in IMO-WI were more profound. Increased levels of Egr-1 were associated with the decrease in Sp1 protein levels. We showed for the first time the competitive interaction between redoxsensitive transcription factors Egr-1 and Spl in the early phases of gastric ulcer development, which might facilitate inducible transcriptional activity of Egr-1 at the expense of reduction in Spl activity.

Key words: transcription factor, Egr-1, Sp-1, peptic ulcer disease, stress, aspirin.

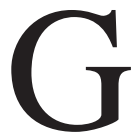

astric ulcer is one of the most widespread pathologies of gastrointestinal tract. Moreover, it has a tendency to increase in occurrence [1]. The main pathogenetic agent for this disorder is the imbalance between aggressive and protective factors. Several factors are considered to be aggressive in this regard, such as the overproduction of hydrochloric acid and pepsin, caused by mucosal hyperplasia in the fundus of the stomach; the vagus nerves hyperexcitability; the overproduction of gastrin; the hyperreactivity of parietal cells; the increased reverse diffusion of protons; the reflux of bile in the stomach; localized disruptions in intramural blood flow; the impaired peristalsis of the gastroduodenal zone of the gastrointestinal tract; the bacterial invasion by Helicobacter pylori (H. pylori) [2]. The protective factors are considered to be the durability of gastroduodenal zone, the mucus cove- ring the mucous membrane of the stomach; active regeneration of surface epithelium; the adequate blood supply; the saliva; the inhibitive action of gastroduodenal system; the basic components of gastric and pancreatic juice [3]. It has been demonstrated by us [4] and others [5] that changes in redox status of the gastric mucosa cells are the main cause of the development of this pathology. Prooxidants may affect cell transcription machinery, changing the activity of redox-sensitive transcription factors [6]. There is poor data concerning the role of redox-sensitive transcription factors in pathogenesis of gastric ulcer.

Egr-1 (Early growth response protein 1) is a redox-sensitive transcription factor (also called Krox24, NGFI-A, zif268). It is an early response protein because various factors, including hypoxia, growth factors, interleukins, hormones, and neurotransmitters cause rapid and profound expression of its gene 
[7]. The Egr-1 gene was first described as a factor stimulating growth of fibroblasts in response to blood serum components, which is localized in chromosome 5q23-q31 and is composed of two exons [8]. The analysis of functional elements of human genome (ENCODE project) [9] has detected Egr-1 binding sites in promoter regions of growth factors EGF, PDGF-A, B; PDGFR-A, -B; VEGF [10], which are crucial to the development and healing of gastric ulcer not just via regulation of angiogenesis, but also by prevention of various types of cell death [11]. It has been demonstrated in studies on mesenchymal stem cells that Egr-1 acts as a transcription factor for numerous converging signal pathways, thus ensuring the regenerative potential of this cell type [10].

The regulatory activity of Egr-1 is interconnected with Sp1 (Specificity protein 1) that is also a transcription factor. Their binding sites are partially overlapping in a common promoter region (-GGGCGG-), which may lead to competition for the binding site in some cases [12, 13].

Both Sp1 and Egr-1 have three zinc finger domains of Cys2His2 type that are responsible for recognition and binding to GC-rich region of promoter [14]. Sp1 is an important transcription factor able to activate or inhibit transcription in response to physiological and pathological stimuli, such as oxidative stress [15]. Sp1 also effects the expression of genes involved in a number of physiological processes, e.g. cell cycle and cell growth regulation, hormone activation, apoptosis and angiogenesis [16].

As Egr-1 and Sp1 both regulate the expression of genes taking part in gastric ulcer pathogenesis (growth factors, cell cycle regulators, etc.), the aim of the present study was to determine their involvement in mechanisms of development of gastric lesions induced by stress and aspirin.

\section{Materials and Methods}

Male white rats (180-220 g of body mass) were used in the experiments. The animals $(n=63)$ were randomly separated into groups of three. The animals had been starved for $24 \mathrm{~h}$ prior to the start of the experiment, with free access to water. At no time during the experiment were the animals subjected to unnecessary cruelty and inhumane killing. The experiments are consistent with the requirements of the European Convention for the Protection of Vertebrate Animals used for Experimental and Other Scientific Purposes (Strasbourg, 1986) and with ethical norms as laid down in the laws of Ukraine.
The rats ( $n=36$ ) were used for the immobilization stress combined with water-immersion (IMOWI) model. The rats were restrained in perforated tubes with a transparent window in top (head) position. The tubes were immersed vertically in water $\left(22{ }^{\circ} \mathrm{C}\right.$ ), so that $2 / 3$ of the animal's body was below the water surface. The animals of the first (control) group were not subjected to any manipulations. The animals of the groups II, III, and IV were subjected to IMO-WI stress for $20 \mathrm{~min}, 1 \mathrm{~h}$, and $3 \mathrm{~h}$, accordingly. Twenty seven rats were used for the aspirin-induced gastric lesions model. The animals were administered aspirin (CJSC "Pharmaceutical firm "Darnitsa") in doses of $10 \mathrm{mg} / \mathrm{g}$ of body mass, dissolved in $0.2 \mathrm{M} \mathrm{HCl}$. The rats of the control group were received intragastric gavage of $0.5 \mathrm{ml}$ of distilled $\mathrm{H}_{2} \mathrm{O}$ (group I - control) or $0.5 \mathrm{ml}$ of $0.2 \mathrm{M}$ $\mathrm{HCl}$ (group II - control). The rats were euthanized $20 \mathrm{~min}, 1 \mathrm{~h}$, and $3 \mathrm{~h}$ post aspirin or control substances $\left(\mathrm{H}_{2} \mathrm{O}\right.$ or $\left.0.2 \mathrm{M} \mathrm{HCl}\right)$ administration.

The rats were euthanized by cervical dislocation, and the stomach was excised. The stomach was opened via its lesser curvative, turned inside out, and washed thoroughly with normal saline. The macroscopic lesions on gastric mucosa were registered by camera, and then the mucous membrane was scraped off and frozen in liquid nitrogen for molecular studies that were to follow.

Protein SH groups content were determined by the difference between total SH groups content and non-protein SH groups content, as assayed with Ellman's reagent [17].

The western blot. In order to determine protein content, the separated gastric mucosa was homogenized in lysis buffer $(0.1 \%$ SDS, $1 \%$ Triton X100, $2 \mu \mathrm{M}$ PMSF) with addition of protease inhibitor cocktail $(16.65 \mathrm{ml} / \mathrm{l})$ and phosphatase inhibitor (1 $\mu \mathrm{M}$ sodium orthovanadate) (Sigma, USA). Total protein concentration was assayed after Bradford with "Bio-Rad protein assay” kit (Bio-Rad, USA).

Proteins (50, 75 or $100 \mu \mathrm{g}$ of protein per well) were separated by electrophoresis in $12 \%, 10 \%$ or 8\% SDS PAA gel, and then transferred to nitrocellulose membrane in accordance with the standard Bio-Rad protocol.

Antibodies to Egr-1 (sc-110, 1:300), Sp-1 (sc-59, $1: 600), \beta$-actin (1:1000) (Santa-Crus Biotech, USA) were used to detect the corresponding proteins in gastric mucosa with consequent incubation with horseradish peroxidase conjugated secondary antibodies diluted 1 : 10000 (anti-mouse antibodies). The results were visualized with ECL reagent. 
mRNA was assayed by RT-PCR with Thermo Scientific reagents (Lithuania). RNA extraction was done by phenolic method. The cDNA was produced in $20 \mu \mathrm{l}$ of PCR reaction buffer containing $2 \mu \mathrm{g}$ of RNA, $1 \mathrm{mM}$ of dNTP, 200 units of reverse transcriptase, 20 units of ribonuclease inhibitor (RiboLock), 20 pmol of reverse primer. The synthesis was done in the following conditions: $65^{\circ} \mathrm{C}-5 \mathrm{~min}$, $45^{\circ} \mathrm{C}-1$ hour, $72{ }^{\circ} \mathrm{C}-5 \mathrm{~min}$. The PCR was done in $30 \mu \mathrm{l}$ of PCR reaction buffer containing $3 \mu \mathrm{l}$ cDNA, $200 \mu \mathrm{M}$ dNTP, 30 pmol of each primer, $2.5 \mathrm{mM}$ $\mathrm{MgCl}_{2}, 1.5$ units of Taq DNA Polymerase (recombinant), (Thermo Scientific).

DNA amplification was done in the following conditions: initial denaturation at $92{ }^{\circ} \mathrm{C}$ for $2 \mathrm{~min}$, then for Egr-1: 30 cycles of DNA denaturation at $92{ }^{\circ} \mathrm{C}$ for $30 \mathrm{~s}$, primer annealing at $65^{\circ} \mathrm{C}$ for $30 \mathrm{~s}$, elongation step at $72{ }^{\circ} \mathrm{C}$ for $40 \mathrm{~s}$; for $\beta$-actin (housekeeping gene) - 28 cycles of DNA denaturation at $95{ }^{\circ} \mathrm{C}$ for $1 \mathrm{~min}$, primer annealing at $49^{\circ} \mathrm{C}$ for $40 \mathrm{~s}$, elongation step at $72{ }^{\circ} \mathrm{C}$ for $1 \mathrm{~min}$. The final elongation was done at $72{ }^{\circ} \mathrm{C}$ for $10 \mathrm{~min}$. The following primer sequences were used in the reaction: for Egr1 - forward gagatgatgctgctgagcaacggg and reverse gtataggtgatgggaggcaaccgg; for $\beta$-actin - forward tgggacgatatggagaagat and reverse attgccgatagtgatgacct. The products of the PCR (20 $\mu \mathrm{l}$ each) were subjected to electrophoretic separation in $2.5 \%$ agarose gel in $0.5 \times \mathrm{TBE}$ buffer at $5-10 \mathrm{~V} / \mathrm{cm}$. The densitometry was done with Phoretix 1D software.
The results of experiments at the least were analyzed statistically via Student's $t$-test. The data is presented as $\mathrm{M} \pm \mathrm{SD}$, the difference was considered statistically significant at $P<0.05$.

\section{Results and Discussion}

We observed hyperemia and isolated petechiae on gastric mucous membrane of rats after $20 \mathrm{~min}$ exposure to IMO-WI. Increased exposure time was associated with worsened clinical picture, for instance, the mean lesion area per stomach after 1 hour IMO-WI stressor exposure was $0.75 \pm 0.95 \mathrm{~mm}^{2}$ $(P<0.05)$, while that after 3 hours exposure was $10.0 \pm 5.2 \mathrm{~mm}^{2}(P<0.05)$ (Fig. 1).

The mechanisms governing the regulation of the activity of redox-sensitive transcription factors by antioxidants involve SH groups' oxidation by cysteine of the transcriptional factor protein molecule [6]. We found that gastric lesions under IMOWI conditions are associated with twofold decrease $(P<0.05)$ of protein thiol groups in gastric mucosa in comparison with the levels in control animals (Fig. 2). This may signify changes in the tissue redox state and may implicate activation of redox-sensitive transcriptional factors.

To prove this assumption, we have demonstrated that 20 min exposure to IMO-WI stressor causes a rapid threefold increase $(P<0.05)$ in Egr-1 protein content within the gastric mucosa of the animals
A

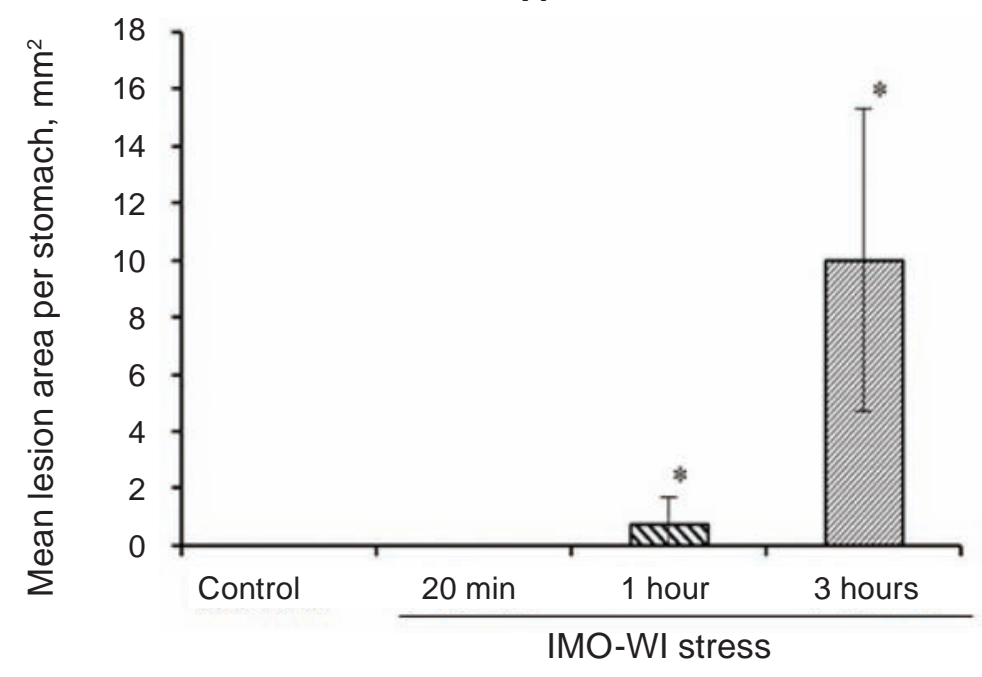

B
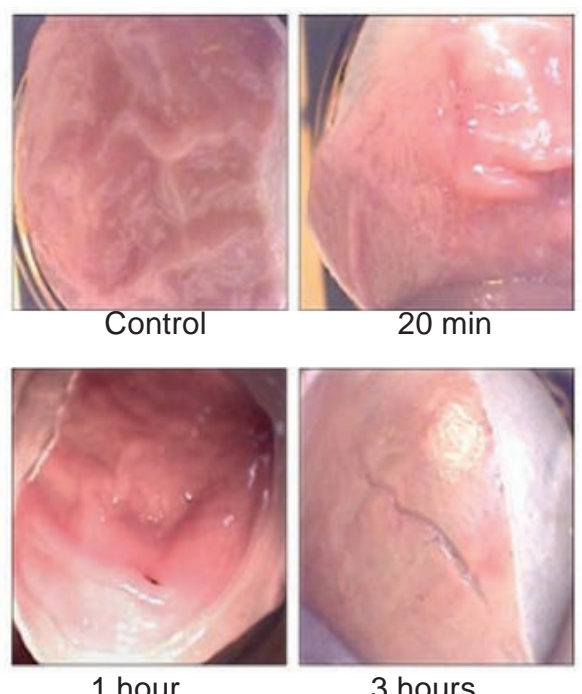

3 hours

Fig. 1. Macroscopic changes in gastric mucous membrane after exposure to IMO-WI stress of various duration. A - numeric values of lesion area, $(M \pm S D ; n=6) ; B$ - sample images of rat stomachs. $* P<0.05$ in comparison to control values 


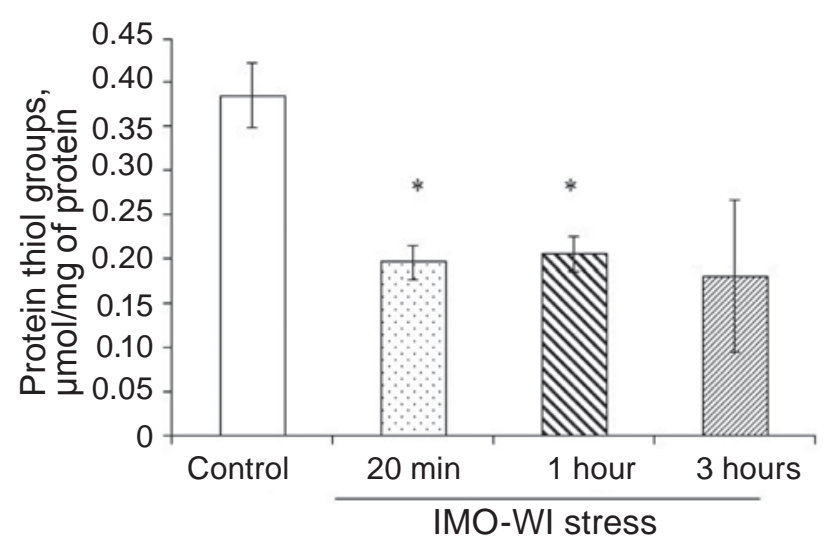

Fig. 2. Protein thiol groups concentration in gastric mucosa after exposure to IMO-WI stress of various duration $(M \pm S E M) . * P<0.05$ in comparison to control values

(Fig. 3, A). Further prolongations in exposure time to $1 \mathrm{~h}$ or $3 \mathrm{~h}$ did not caused increase in its level, which remained higher than that of control group $(P<0.05)$. Similarly, we have detected 23-times, 22-times, and 19.8-times increase in Egr-1 mRNA expression $(P<0.05)$ after $20 \mathrm{~min}, 1 \mathrm{~h}$ and $3 \mathrm{~h}$ of IMO-WI stressor exposure (Fig. $3, B$ ). These results

\section{A}
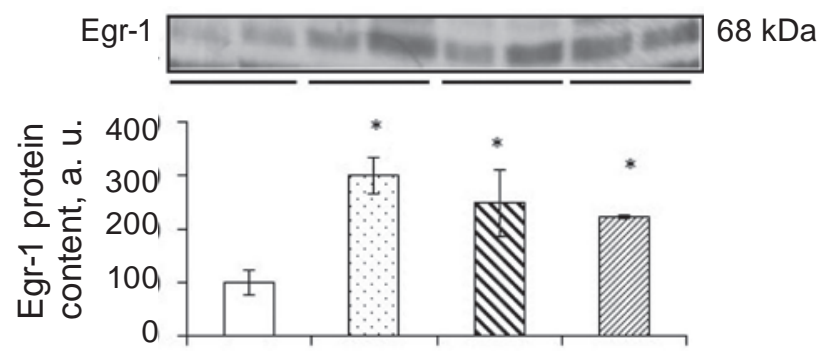

B

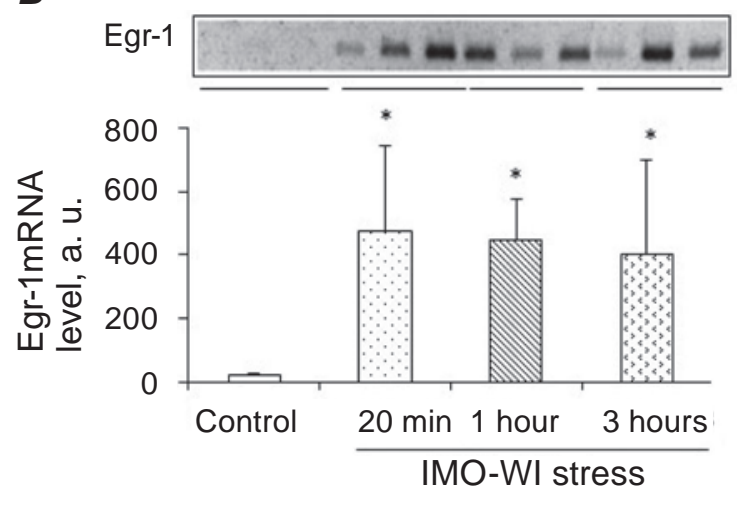

give evidence to the increased Egr-1 content as a result of its de novo synthesis.

Several factors are generally considered to be the main exogenous etiological effectors associated with development and recurrence of gastric ulcer disease, for instance the psychological and social stress, adverse effects of nonsteroidal antiinflammatory drugs, among which acetylsalicylic acid (aspirin) is the most widely used [3]. To confirm the ubiquitous role of Egr-1 in gastric ulcer pathogenesis, we determined Egr-1 expression levels in aspirin-induced gastric ulcer model conditions. We observed gastric mucosa hyperemia and petechiae in animals that had been administered aspirin $20 \mathrm{~min}$ prior to examination. We also observed minor damage to gastric mucous membrane. We found massive hemorrhage, erosions, and ulcers 1 hour after the aspirin exposure with mean area of $44.0 \pm 31.4 \mathrm{~mm}^{2}$ $(P<0.05)$. The mucosa condition was observed to worsen three hours post exposure. The mean lesions area was $85.0 \pm 54.1 \mathrm{~mm}^{2}(P<0.05)$ (Fig. 4).

We observed Egr-1 protein expression levels in rat gastric mucosa to increase 1.4-times $(P<0.05)$ 20 min after the aspirin exposure. Longer exposure time caused increased expression, which peaked at

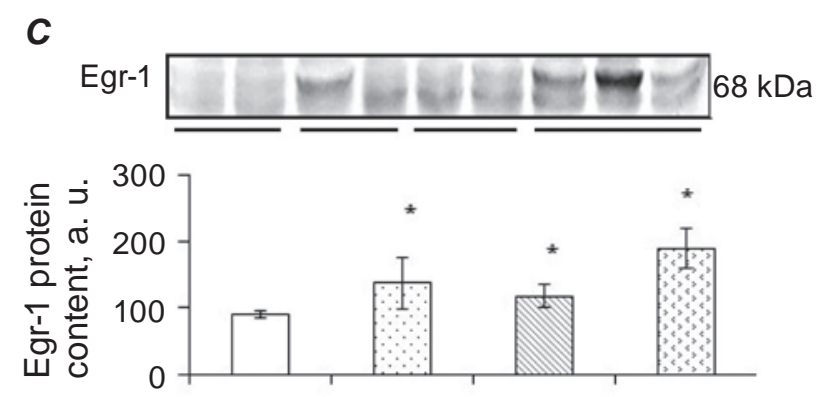

D

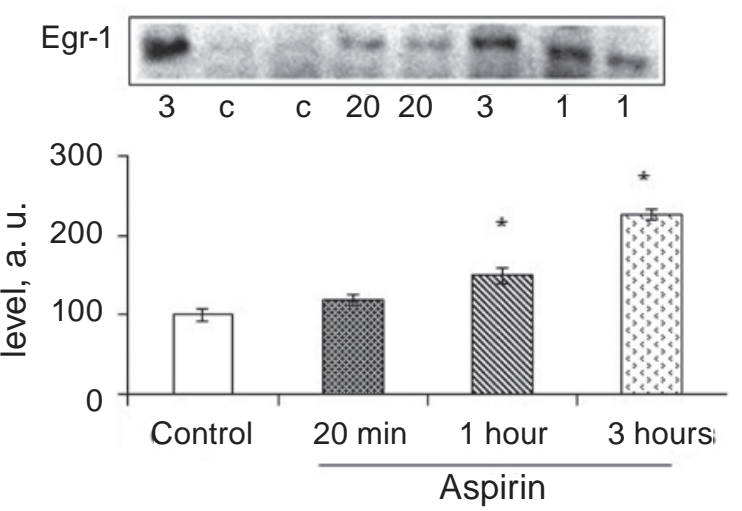

Fig. 3. Egr-1 protein and mRNA content in rat gastric mucosa after exposure to IMO-WI stress $(A, B)$ and to aspirin $(C, D)$ of various duration. $A, C$-western blot assay results normalized to $\beta$-actin levels; $B, D-R T$ $P C R$ results normalized to $\beta$-actin levels $(M \pm S D) . * P<0.05$ in comparison to control values 
$3 \mathrm{~h}$ and was double that of control group $(P<0.05)$ (Fig. 3, B). Higher Egr-1 protein levels were accompanied by higher Egr-1 mRNA levels. Egr-1 mRNA increased 1.5-fold $(P<0.05) 1$ h post aspirin administration, and 2.3 -fold $(P<0.05) 3 \mathrm{~h}$ post aspirin administration in comparison with control group (Fig. 3, C). These data correlate well with the results that had been obtained in IMO-WI model experiments. This may signify the importance of Egr-1 as a universal transcription factor in gastric ulcer pathogenesis. Underscoring our conclusions is the evidence of increased Egr-1 protein and mRNA expression during early stages of cysteamine-induced duodenal ulcer, while Egr-1 antisense oligonucleotide administration caused the clinical picture of the condition to worsen [18].

According to publications, Egr-1 may act by binding to promoter regions of genes that are identical to that of another zinc-binding transcription factor Sp1 [13, 19]. Regulatory activity of Egr-1 and Sp1, admittedly, may include both competition and complementation. It is known that hypoxia activates expression of phenylethanolamine N-methyltransferase, and adrenalin-synthesizing enzyme, in adrenal medulla under immobilization stress via increased mRNA expression of Egr-1 and Sp1 and formation of their protein-protein complex [20]. The cis-regulatory element of Egr-1, which is partially overlapping with Sp1, has been found in tyrosine hydroxylase gene promoter region. Egr-1 binds to the tyrosine hydroxylase gene promoter in rat adrenal cortex under immobilization stress conditions through competitive displacement of Sp1 [21]. It has been shown in the in vitro studies on endothelial cells that Egr-1 and Sp1 are interchangeable in the promoter region of PDGF-B gene depending on their concentration in the nucleus and affinity to the binding site [22].

In our experiments IMO-WI stress-induced lesions caused gradual decrease in Sp1 levels in rat gastric mucosa, which became statistically significant in just 20 min after the beginning of exposure to stressor $(P<0.05)$ (Fig. 5, $A)$. We observed similar tendencies of gradual Sp1 content decrease in the case of aspirin-induced gastric ulcer model. Sp1 content was 1.5 folds lower $(P<0.05)$ after $3 \mathrm{~h}$ of aspirin exposure than that in the animals of the control group (Fig. 5, B). These results support the assumption of competitive interaction between Egr-1 and Sp1 in experimental ulcer models. This conclu-
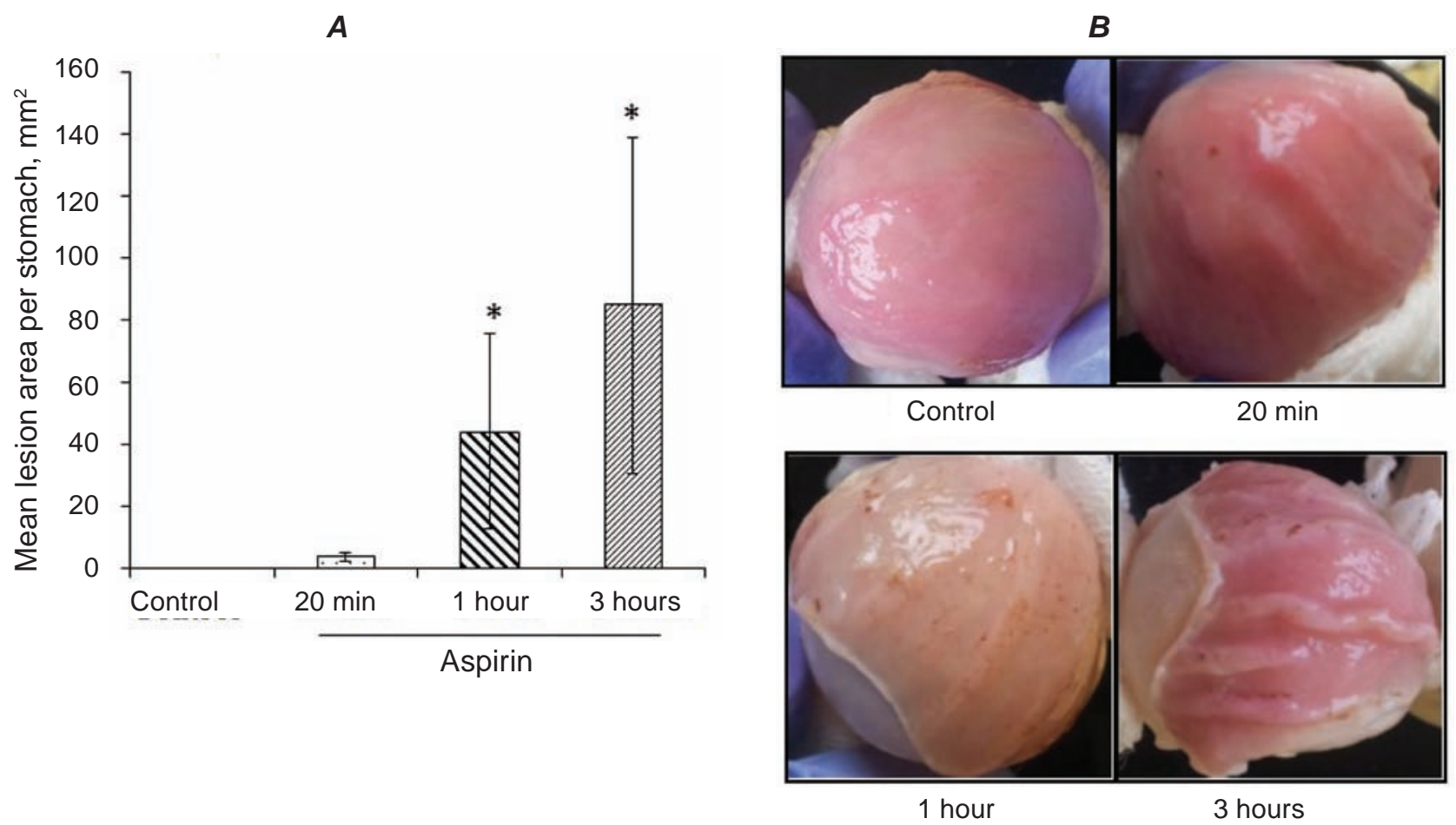

Fig. 4. Macroscopic changes in gastric mucous membrane after exposure to aspirin of various duration. Anumeric values of lesion area $(M \pm S D ; n=6) ; B$ - sample images of rat stomachs. ${ }^{*} P<0.05$ in comparison to control values 
$A$

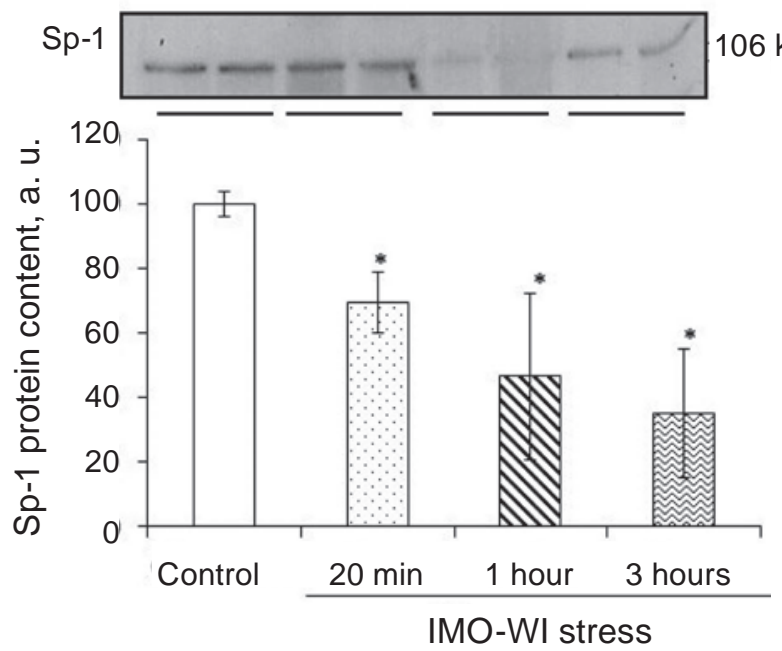

B
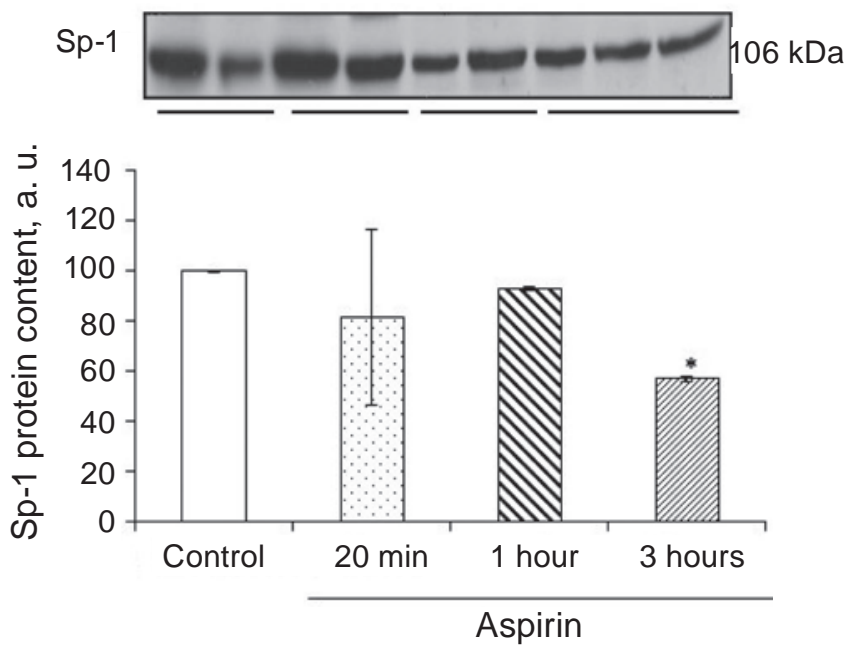

Fig. 5. Spl protein content in rat gastric mucosa after exposure to IMO-WI stress (A) and to aspirin (B) of various duration. Western blot assay results are normalized to total protein levels $(M \pm S D) . * P<0.05$ in comparison to control values

sion is also supported by our previous data from experimental ulcerative colitis studies, in which Egr-1/ Sp1 complex disintegration under colon lesion conditions had correlated in time with Sp1 level decrease in colon mucosa, while Egr-1 concentration and its affinity for DNA remained highly elevated [23]. The evidence from studies by others likewise gives credence to our conclusions [12, 22] that overexpression or overactivation of certain factor causes increase in its cellular concentration with consequent displacement of the 'competitor' in the promoter region of the gene.

Thus, gastric lesions development under experimental ulcer conditions is associated with increased expression of the redox-sensitive transcriptional factor Egr-1, which is apparently activated via oxidation of its thiol groups. Egr-1 level increase is paralleled by decrease in Sp1 level. This facilitates the elevated inducible transcriptional activity of Egr- 1 at the expense of the repressed transcriptional activity of Sp1.

\section{РЕДОКСЧУТЛИВІ ТРАНСКРИПЦИЙНІ ФАКТОРИ EGR-1 TA SP1 У ПАТОГЕНЕЗІ ЕКСПЕРИМЕНТАЛЬНОЇ ВИРАЗКИ ШЛУНКА}
С. М. Береговийㅁ, T. М. Червінська ${ }^{1}$, А. С. Драницина ${ }^{1}$ Ш. Сабо 2 ,
Г. М. Толстанова

${ }^{1} \mathrm{HНЦ} \mathrm{«Інститут} \mathrm{біології»,} \mathrm{Київський} \mathrm{національний}$ університет імені Тараса Шевченка, Україна; ${ }^{2}$ Каліфорнійський університет, Ірвайн, США; e-mail: gtolstanova@gmail.com

Зміни редокс-статусу клітин слизової оболонки шлунка $є$ основними чинниками розвитку ерозивно-виразкових уражень в ньому. Прооксиданти здатні впливати на транскрипційний апарат клітини, змінюючи активність редоксчутливих транскрипційних факторів. Враховуючи той факт, що Egr-1 та Sp-1 регулюють транскрипцію генів, асоційованих із патогене- 
зом виразкової хвороби шлунка (фактори росту, регулятори клітинного циклу тощо), метою цієї роботи була перевірка їх участі в механізмах розвитку уражень шлунка, що спричинені стресом та аспірином. Дослідження проведені на щурахсамцях (180-220 г). Виразки шлунка моделювали водно-іммобілізаційним стресом (BI-стрес) чи введенням аспірину (10 мг/100 г). Тварин умертвляли через 20 хв, 1 та 3 год. Експресію генів визначали методами Вестерн-блот аналізу та ПЛР зі зворотною транскрипцією; рівень $\mathrm{SH}-$ груп - за методом Еллмана. Встановлено, що поступове збільшення площі ерозивно-виразкових уражень шлунка асоціювалось зі зменшенням у 2 рази $(P<0,05)$ рівня SН-груп протеїнів у слизовій оболонці шлунка щурів. Ці зміни спричиняли вірогідне підвищення експресії протеїну та мРНК Egr-1 на обох моделях виразок, причому виразніше за дії BI-стресу. Підвищення рівня Egr-1 супроводжувалось паралельним зниженням рівня Sp1. Вперше встановлено, що редоксчутливі транскрипційні фактори Egr-1 та Sp1 вступають в конкурентну взаємодію на ранніх етапах утворення виразок шлунка, що може сприяти збільшенню індуцибельної транскрипційної активності Egr-1 за рахунок зменшення Sp1 транскрипційної активності.

К л ю ч о в і с л о в а: транскрипційний фактор, Egr-1, Sp-1, виразкова хвороба шлунка, стрес, аспірин.

\section{РЕДОКСЧУВСТВИТЕЛЬНЫЕ ТРАНСКРИПЦИОННЫЕ ФАКТОРЫ EGR-1 И SP1 В ПАТОГЕНЕЗЕ ЭКСПЕРИМЕНТАЛЬНОЙ ЯЗВЫ ЖЕЛУДКА}

\section{С. М. Береговойํ, Т. Н. Червинская ${ }^{1}$, А. С. Драницина A. Н. Толстанова}

1УНЦ «Институт биологии», Киевский национальный университет имени Тараса Шевченко, Украина;

${ }^{2}$ Калифорнийский университет, Ирвайн, США; e-mail: gtolstanova@gmail.com

Изменения редокс-статуса клеток слизистой оболочки желудка являются основными факторами развития эрозивно-язвенных поражений. Прооксиданты способны влиять на транскрипционный аппарат клетки, изменяя ак- тивность редоксчувствительных транскрипционных факторов. Учитывая тот факт, что Egr-1 и Sp-1 регулируют транскрипцию генов, ассоциированных с патогенезом язвенной болезни желудка (факторы роста, регуляторы клеточного цикла и т.д.), целью данной работы была проверка их участия в механизмах развития стресс- и аспиринвызванных поражений желудка. Исследования проведены на крысах-самцах (180-220 г). Язвы желудка моделировали водноиммобилизационным стрессом (ВИ-стресс) или введением аспирина (10 мг/100 г). Животных умертвляли через 20 мин, 1 и 3 ч. Экспрессию протеинов определяли методом Вестерн-блот анализа и ПЦР с обратной транскрипцией; уровень SН-групп - с использованием реактива Эллмана. Установлено, что постепенное увеличение площади эрозивно-язвенных поражений желудка крыс ассоциировалось с уменьшением в 2 раза $(P<0,05)$ уровня протеиновых $\mathrm{SH}-г р у п п ~$ в его слизистой оболочке. Эти изменения вызвали достоверное повышение экспрессии протеина и мРНК Egr-1 на обеих моделях язв, причем более значительное на фоне ВИ-стресса. Повышение уровня Egr-1 сопровождалось параллельным снижением уровня Sp1. Впервые установлено, что редоксчувствительные транскрипционные факторы Egr-1 и Sp1 вступают в конкурентное взаимодействие на ранних этапах язвообразования в желудке, что может способствовать увеличению индуцибельной транскрипционной активности Egr-1 за счет уменьшения Sp1 транскрипционной активности.

Кл ю чевы е с лов в: транскрипционный фактор, Egr-1, Sp-1, язвенная болезнь желудка, стресс, аспирин.

\section{References}

1. Larichev A. B., Maiorov M. I., Favstov S. V., Shalop'ev A. G. Clinical-epidemiological aspects of gastric and duodenum ulcer. Vestnik Khirurgii im. I. I. Grekova. 2014;173(2):100-104. (In Russian).

2. Ramakrishnan K., Salinas R. C. Peptic ulcer disease. Am. Fam. Physician. 2007;76(7):10051012.

3. Laine L, Takeuchi K, Tarnawski A. Gastric mucosal defense and cytoprotection: bench to bedside. Gastroenterology. 2008;135(1):41-60.

4. Dvorshchenko C., Vakal S., Beregovyi S. Lipid peroxidation in rat gastric mucosa subcellular 
fraction under experimental ulcer. Visn. Kyiv Nat. T. Shev. Univ. Probl. Regul. Physiol. Function. 2010;(13):4-5. (In Ukrainian).

5. Kwiecień S., Brzozowski T., Konturek P. Ch., Konturek S. J. The role of reactive oxygen species in action of nitric oxide-donors on stressinduced gastric mucosal lesions. J. Physiol. Pharmacol. 2002;53(4(2)):761-773.

6. Marinho H. S., Real C., Cyrne L., Soares H., Antunes F. Hydrogen peroxide sensing, signaling and regulation of transcription factors. Redox. Biol. 2014;2:535-562.

7. Thiel G., Cibelli G. Regulation of Life and Death by the Zink Finger Transcription Factor Egr-1. J. Cell. Physiol. 2002;193(3):287-292.

8. Sukhatme V. P., Cao X. M., Chang L. C., TsaiMorris C. H., Stamenkovich D., Ferreira P. C., Cohen D. R., Edwards S. A., Shows T. B., Curran T., Le Beau M. M., Adamson E. D. A zinc finger-encoding gene coregulated with c-fos during growth and differentiation, and after cellular depolarization. Cell. 1988;8(53(1)):3743.

9. The ENCODE (Encylopedia of DNA elements) Project. Science. 2004;306(5696):636-640. Available at http://www.sciencemag.org.

10. Kerpedjieva S.S., Kim D.S., Barbeau D.J., Tamama K. EGFR ligands drive multipotential stromal cells to produce multiple growth factors and cytokines via early growth response-1. Stem. Cells Dev. 2012;21(13):2541-2551.

11. Szabo S., Deng X., Khomenko T., Chen L., Tolstanova G., Osapay K., Sandor Z., Xiong $X$. New Molecular Mechanisms of Duodenal Ulceration. Ann. N. Y. Acad. Sci. 2007;1113(1):238-255.

12. Silverman E. S., Collins T. Pathways of Egr-1mediated gene transcription in vascular biology. Am. J. Pathol. 1999;154(3):665-670.

13. Minc E., de Coppet P., Masson P., Thiery L., Dutertre S., Amor-Guéret M., Jaulin C. The human copper-zinc superoxide dismutase gene (SOD1) proximal promoter is regulated by Sp1, Egr-1, and WT1 via non-canonical binding sites. J. Biol. Chem. 1999;274(1):503-509.

14. Briggs M. R., Kadonaga J. T., Bell S. P., Tjian R. Purification and biochemical characterization of the promoter-specific transcription factor, Sp1. Science. 1986;234(4772):47-52.
15. Ryu H., Lee J., Zaman K., Kubilis J., Ferrante R. J., Ross B. D., Neve R., Ratan R. R. Sp1 and Sp3 are oxidative stress-inducible, antideath transcription factors in cortical neurons. J. Neurosci. 2003;23(9):3597-3606.

16. Santiago F. S., Ishii H., Shafi S., Khurana R., Kanellakis P., Bhindi R., Ramirez M. J., Bobik A., Martin J. F., Chesterman C. N., Zachary I. C., Khachigian L. M. Yin Yang-1 inhibits vascular smooth muscle cell growth and intimal thickening by repressing p21WAF1/Cip1 transcription and p21WAF1/Cip1-Cdk4-cyclin D1 assembly. Circ. Res. 2007;101(2):146-155.

17. Ellman G. L. Tissue sulfhydryl groups. Arch. Biochem. Biophys. 1959;82(1):70-77.

18. Khomenko T., Szabo S., Deng X., Jadus M.R., Ishikawa H., Osapay K., Sandor Z., Chen L. Suppression of early growth response factor-1 with egr-1 antisense oligodeoxynucleotide aggravates experimental duodenal ulcers. Am. J. Physiol. Gastrointest. Liver Physiol. 2006;290(6):1211-1218.

19. Liu M., Wang X., Peng Y., Shen S., Li G. Egr1 regulates the transcription of NGX6 gene through a Sp1/Egr-1 overlapping site in the promoter. BMC Mol. Biol. 2014;15:14.

20. Wong D. L., Tai T. C., Wong-Faull D. C., Claycomb R., Kvetnansky R. Adrenergic responses to stress: transcriptional and posttranscriptional changes. Ann. N. Y. Acad. Sci. 2008;1148:249-256.

21. Papanikolaou N. A., Sabban E. L. Sp1/Egr1 motif: a new candidate in the regulation of rat tyrosine hydroxylase gene transcription by immobilization stress. J. Neurochem. 1999;73(1):433-436.

22. Khachigian L. M., Fries J. W., Benz M. W., Bonthron D. T., Collins T. Novel cis-acting elements in the human platelet-derived growth factor B-chain core promoter that mediate gene expression in cultured vascular endothelial cells. J. Biol. Chem. 1994;269(36):22647-22656.

23. Tolstanova G. M., Ostapchenko L. I. Interaction between transcription factors Egr-1 and Sp1 in inflammatory bowel disease pathogenesis. Med. Chem. 2010;(3):10-15. (In Ukrainian).

Received 19.02.2015 